\title{
DISCONTINUOUS ADOPTION OF SOCIAL MEDIA PLATFORM
}

\author{
Chih-Chin Liang \\ National Formosa University \\ lgcwow@gmail.com
}

\begin{abstract}
Microsoft ended its involvement in social media at the beginning of 2013, due to a gradual global decrease in the user numbers of MSN Messenger. However, Microsoft's major competitor, Facebook, gradually supplanted Microsoft and became the most popular social media platform in Taiwan. The decrease in the number of users of Microsoft's social media platform reflected changes in discontinuous social media adoption. If people enjoy talking with their friends through a particular social media, they will fall into flow experience, which may influence their attitude toward and use of social media. This study examines flow experience and the discontinuous adoption on social media based on a survey of 400 users. Participants were asked to discuss their experiences with changes to their favorite social media in Taiwan regarding chatting with their friends. The analytical results demonstrate that flow experience significantly influences perceived ease of use, together with attitude toward and intention to use social media. Users adopted new social-network applications based on their better flow experiences of using social media. The other practical implications are also illustrated.
\end{abstract}

Keywords: Social Media, Flow Experience, Discontinuous Adoption

\section{INTRODUCTION}

Microsoft Live Messenger (MSN) ceased to be available globally on April 4, 2013 ${ }^{1,2}$. This event shocked social network users in Taiwan, because MSN had been the favorite social application for communicating with friends ${ }^{2}$. However, the evolution of social networking witnessed Facebook Messenger occupy a larger market than MSN had ${ }^{3,4}$. The report from comScore $^{\circledR}$ shows that Facebook (374 minutes per user) was users' most used application in 2013. Facebook Messenger overtook Yahoo! Wretch in monthly usage volume in 2010 , to become the dominant social media in 
Taiwan. Additionally, one year before Microsoft announced its plan to end the MSN service, the use of social media demonstrated that Facebook dominated usage in terms of average minutes of use per visitor ${ }^{5}$. The decision to discontinue MSN was based on many reasons from the financial or competitive perspectives ${ }^{6,7,8}$, but customers' discontinued use and continuous adoption of the applications are important issues ${ }^{9}$. Few studies have discussed the discontinued adoption of applications, especially social media applications ${ }^{10,11,12}$. The dramatic decline in the use of MSN is without precedent. The study of this decline can fill the gap in research on discontinuous intention to use, provide evidence within user behavior, and examine the most popular social media products among people in Taiwan.

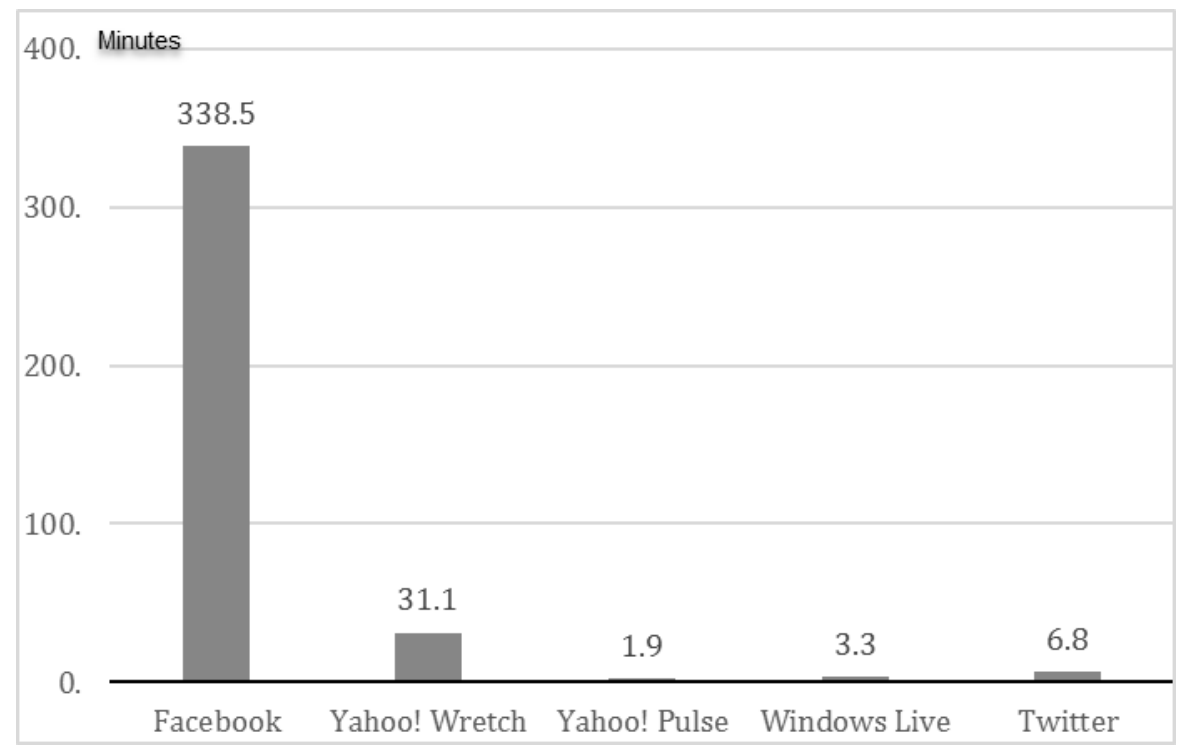

Figure 1. Average minutes a day per Taiwan visitor spending on social media in 2013

Social media networks share similar characteristics, generally referred to as the technology acceptance model. These characteristics include usefulness and ease of use, which affect user adoption behavior ${ }^{13,14,15}$. In other words, people choose their favorite social media platform based on these characteristics. However, superior characteristics attract people and influence their attitude toward the continuous use of a social media platform $^{16,17,18}$. The discontinuous adoption of social media must result from external effects, rather than just because of adopting an application.

Phubbers are common in contemporary Taiwan society, with the technology development and the growing population of mobile-device users $^{19}$. Wikipedia (http://en.wikipedia.org/wiki/Phubbing) defines a 
phubber as a smartphone user that focuses on using mobile devices while ignoring other businesses. Namely, the behavior of a phubber represents the one in a flow status ${ }^{3}$. The flow status influences customer use of software application ${ }^{20,21,22,23,24}$. Mauri et al. ${ }^{3}$ demonstrated that flow status relates to the use of social media. Additionally, investigations have demonstrated that such a focus represents that users fall into a flow status that also influences perceived usefulness, ease of use, and attitude toward and intention to use technological applications ${ }^{20,21,22,23,24}$. If people are experiencing a pleasure flow state when they use a social media application, that application should become the social media application they use most frequently ${ }^{25,26}$. Thus, if a software application can attract customers' eyes in the flow status, then the customers will use the software application continuously if they are often involved in the flow status ${ }^{27}$. The so-called "flow status" of social-media users is significant in identifying the reasons for continuous preferences in this regard, but no investigations have discussed the impact of the flow status on users' discontinued use of a social-media application. In summary, discussions of the relationships between flow experiences and the changes of adoption of social media can aid the understanding of the discontinuous adoption of social media ${ }^{20,24,28}$. Although previous studies discussed the discontinuous adoption of social media or online services ${ }^{10,11,12}$, there are few papers that discussed the impacts of flow experience. Kelleher and Sweetser ${ }^{10}$ discussed the discontinuous adoption in university communities. However, the effect of flow experience on discontinuous adoption is worthy of study. Wirtz and Göttel ${ }^{11}$ also mentioned potential research areas including discontinuous adoption of social media. Liang and Huang ${ }^{12}$ explored the changes of adoption of social media of office workers, but the research is not based on the flow experiences.

This study discusses the relationships among flow experiences, perceived ease of use, perceived usefulness, and attitude toward and intention to use social media. The rest of this paper is organized as follows. Section 2 reviews the pertinent literature. Section 3 then details the research method and proposed questionnaire. Subsequently, Section 4 summarizes the analytical results, and Section 5 illustrates the managerial implications. Conclusions are finally drawn in Section 6, along with recommendations for future research. 


\section{LITERATURE REVIEW}

\subsection{Social Media}

A social media platform is one that allows all of its participants to communicate with each other through voice or text and exchange information of interest with friends, co-workers, and family members. Examples include Microsoft MSN Live Messenger, Yahoo! Messenger, Skype, Twitter, and Facebook Messenger. In this study of the comparison between social media platforms, communication is the main common feature between MSN Live Messenger and Facebook Messenger. MSN and Facebook have been two of the most popular social-networking applications in Taiwan ${ }^{29.30,31}$. However, MSN started phasing out Messenger at the beginning of 2013. Today, Facebook has become the most popular social media platform in Taiwan. Various factors should affect such an evolution in the user adoption of social media.

To be widely adopted, a software application must be easy to use ${ }^{32,33}$. To be popular, a software must be common ${ }^{34}$. Furthermore, the interface of an application must be user-friendly ${ }^{35,36}$. Therefore, perceived ease of use influences user adoption of social media. To clarify the differences between the perceived ease of use of the current adopted social media and that of the previous favorite, perceived ease of use must be defined to allow comparison. In this investigation, the perceived ease of use is defined as the degree to which the currently adopted social media exceeds that of the former favorite in terms of perceived ease of use. Along with user behaviors related to the adoption of software applications, perceived usefulness is also important in user adoption of favorite applications ${ }^{32,37,38}$. This study applies the operational definition of perceived usefulness as follows: the current adopted social media is perceived as more useful than the previous favorite. Users adopt social-networking applications because they can help users spread useful and interesting information ${ }^{39,40}$. Additionally, based on the literature, perceived ease of use influences perceived usefulness on web applications $23,27,41$.

\subsection{Attitude Toward and Intention to Use Social Media}

When people can easily share information with friends via a software application, they tend to adopt that application for social networking. Perceived ease of use affects users' attitude toward web application ${ }^{23,27}$ and further affects social media ${ }^{42,43}$. If people can easily exchange information with friends via a social networking application, then they will consider the adoption of that application worthwhile ${ }^{44}$. Social-networking applications gain popular adoption if they allow users to communicate with friends to 
exchange interesting texts, photographs, and video ${ }^{45,46}$. People can attract the attention of friends by posting interesting text, photographs, and video in chat rooms or with a group of friends. People who can efficiently interact with friends or relax are more likely to use social media ${ }^{47}$. The attitude toward and intention to use a social media platform can be affected by friends' shared information. The operational definition of this attitude toward discontinuous use of social media is such that people adjust the amount of attention they devote to different social media. This study uses the operational definition of intention to use social media: people tend to utilize the currently adopted social media more than social media that have diminished in popularity. Accordingly, this investigation tests the following hypotheses to verify the application of theory.

H1: Perceived ease of use positively influences user attitudes toward discontinuous use of social media when users decide to change their preferred social media platform.

H2: Perceived usefulness positively influences user attitudes toward discontinuous use of social media when users decide to change their preferred social media platform.

H3: Attitudes toward discontinuous using social media positively influence user intention of discontinuous use of social media when users decide to change their preferred social media platform.

H4: Perceived ease of use positively influences perceived usefulness when users decide to change their preferred social media platform.

\subsection{Flow Experience}

Csikszentmihalyi proposed flow theory in $1990{ }^{48,49}$. Research shows that humans are grouping animals, meaning that everyone needs to communicate with other people to enjoy life. Csikszentmihalyi claimed that concentration, "being lost in time", enthusiasm, and excitation are associated with being in the flow state ${ }^{3}$. Users of a social network enter into flow state when they are communicating or sharing information with their friends ${ }^{50,51}$. If users experienced mostly a pleasure flow state when they use social media, they used that form of social media most frequently $25,26,27$. However, the flow status affected users' discontinuously adoption of social media is still unclear. It is worth seeking to understand changes in user behaviors in relation to social media to fill the research gap. The purpose of this investigation is to identify the factors that are influenced by flow experience, which may be involved in switching to different social networking applications. The operational definition of the greater flow experience is such that the current adopted social media provides more flow 
experiences than the previous favorite. Appendix 1 presents the questionnaire items concerning flow experience that are used in this study. Accordingly, this study tests the following hypotheses concerning relevant causal relationships (Figure 2).

H5: Flow experience positively influences perceived ease of use when users decide to change their preferred social media platform.

H6: Flow experience positively influences perceived usefulness when users decide to change their preferred social media platform.

H7: Flow experience positively influences user attitudes toward social media when users decide to change their preferred social media platform.

H8: Flow experience positively influences users' intention to discontinue use of social media when the user decided to change their preferred social media platform.

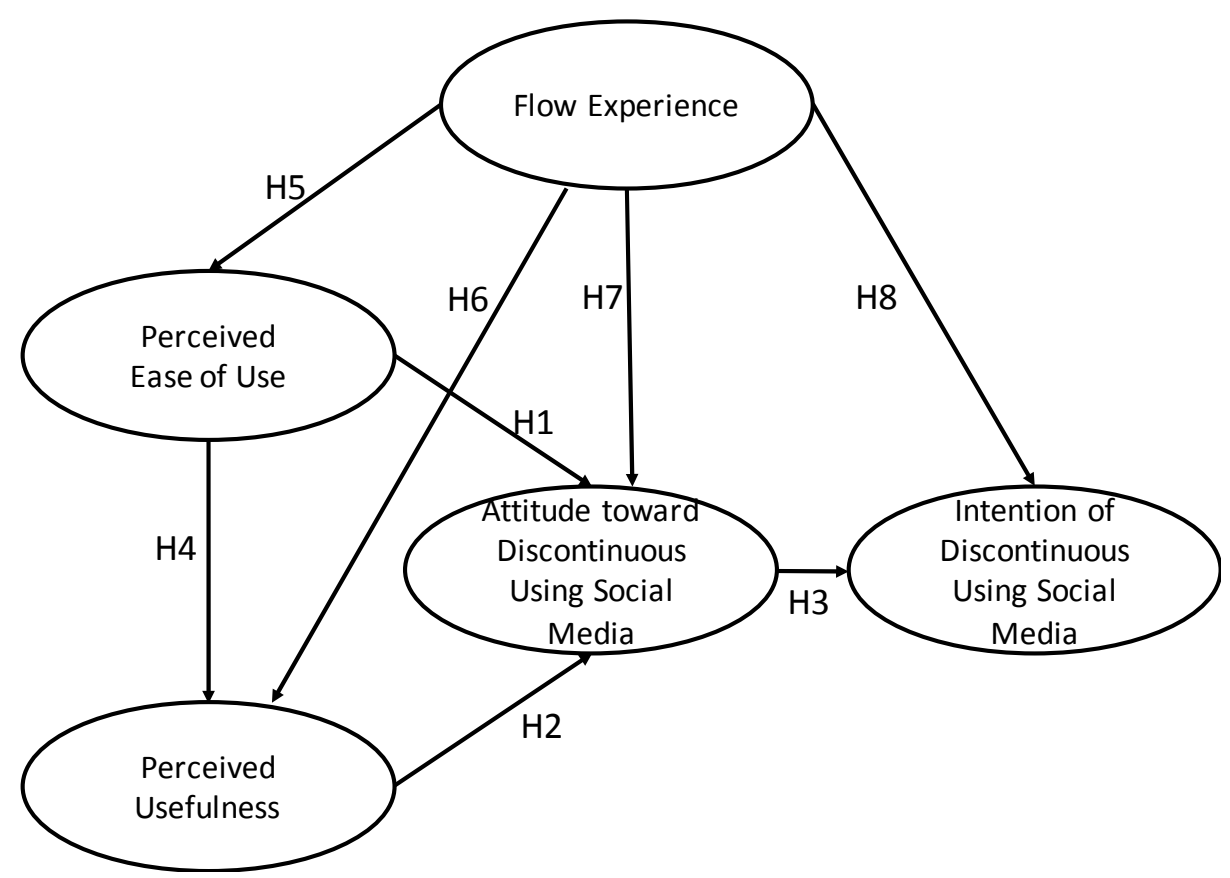

Figure 2. Research Model

\section{RESEARCH METHOD}

Based on the above descriptions of the evolution of social networks, experienced users regarding changes in social networking applications are surveyed for their views on perceived ease of use and usefulness of these 
applications and their attitude toward and intention to use social networking applications, as well as flow experienced when using such platforms. A causality relationship analysis was then conducted using SPSS AMOS version 18 to validate the above hypotheses.

The questionnaire comprises three parts and has been modified using pre-testing. The first part, dealing with perceived ease of use, includes 7 questionnaire items. The second part, dealing with perceived usefulness, comprises 4 questionnaire items. The third part, dealing with users' attitude toward discontinuous using social media, comprises 4 questionnaire items. The fourth part, dealing with the intention toward discontinuous use of social media, comprises 4 questionnaire items. The fifth part, dealing with flow experience, comprises 4 questionnaire items (Appendix 1). The questionnaire design used a 5-point Likert scale to allow participants to indicate their answers to each item on a scale ranging from "strongly disagree" to "strongly agree".

A pretest was conducted to confirm the reliability and validity of the questionnaire using 200 participants. A principal component analysis (PCA) was performed. The analytical results demonstrate that the four constructs can be used in the confirmatory factor analysis. Most of the question items are kept from PCA because the Cronbach's $\alpha$ is larger than 0.7 at the pretest $^{52,53}$. In sum, EU-6, EU-7, US-3, and US-4 are eliminated from the following analysis because of the low Cronbach's $\alpha$.

A stratified random sampling was undertaken to obtain samples from all parts of Taiwan - northern, central, southern, eastern, and island offshore. This investigation surveyed randomly sampled college students. A fair coin toss was employed to select universities in a region: if the face side was up, then the university was included in the sampling pool. The questionnaire will be delivered to the participants on campus. The proportions of participants included in this investigation by Taiwanese region were 134 northern (33.50\%), 115 central (28.75\%), 86 southern $(21.50 \%)$ and 65 eastern and offshore island (16.25\%). To ensure the accuracy of this survey, the total of participants was greater than $300^{54}$.

The completed questionnaires were analyzed with SPSS Statistics ${ }^{\mathrm{TM}}$ version 18.0. The causal relationship among factors was analyzed in SPSS AMOS $^{\mathrm{TM}}$ version 16.0. 


\section{ANALYTICAL RESULTS}

184 males (46\%) and 216 females (54\%) responded to the questionnaire survey. All respondents were between 18 and 24 years old. This section verifies the causal relationship among perceived ease of use, perceived usefulness, attitude toward discontinuous use of social media, intention of discontinuous using social media, and flow experience using the structure equation model. The internal structure fit reveals the qualification of aforementioned dimensions (Table 1). The average variance extracted for each dimension exceeds $0.5^{55}$. Furthermore, the composite reliability of each dimension exceeds $0.6^{5}$. The average variance extracted is valid. The individual item reliabilities of each questionnaire item exceed 0.5. Table 2 shows the discriminant validity. Only one AVE value (0.522) is smaller slightly than the correlation between constructs "Perceived Usefulness" and "Intension of Discontinuous Using Social Media" (0.531). The others are valid based on the Fornell-Larcker method ${ }^{56}$.

Table 1. Basic fit and internal structural fit

\begin{tabular}{|c|c|c|c|c|c|c|c|c|}
\hline Construct & Q. ID & $\begin{array}{l}\text { Standardized } \\
\text { Factor Load }\end{array}$ & $\begin{array}{l}\text { Avg. } \\
\text { Score }\end{array}$ & $\begin{array}{l}\text { Std. } \\
\text { Dev. }\end{array}$ & Means & $\begin{array}{c}\text { Individual } \\
\text { Item } \\
\text { Reliability }\end{array}$ & $\begin{array}{l}\text { Composite } \\
\text { Reliability }\end{array}$ & $\begin{array}{l}\text { Average } \\
\text { Variance } \\
\text { Extracted }\end{array}$ \\
\hline \multirow{4}{*}{$\begin{array}{l}\text { Perceived } \\
\text { usefulness }\end{array}$} & PU-2 & 0.833 & 5.36 & 0.49 & 4.23 & 0.694 & \multirow{4}{*}{0.913} & \multirow{4}{*}{0.723} \\
\hline & PU-4 & 0.881 & 5.33 & 0.48 & 4.34 & 0.776 & & \\
\hline & PU-3 & 0.867 & 5.36 & 0.33 & 4.21 & 0.752 & & \\
\hline & PU-1 & 0.819 & 5.31 & 0.61 & 3.99 & 0.671 & & \\
\hline \multirow{5}{*}{$\begin{array}{l}\text { Perceived } \\
\text { Ease of Use }\end{array}$} & EU-5 & 0.867 & 4.82 & 0.41 & 4.26 & 0.752 & \multirow{5}{*}{0.948} & \multirow{5}{*}{0.784} \\
\hline & EU-1 & 0.903 & 5.09 & 0.62 & 4.32 & 0.815 & & \\
\hline & EU-3 & 0.875 & 5.05 & 0.51 & 4.29 & 0.766 & & \\
\hline & EU-4 & 0.870 & 4.89 & 0.63 & 4.64 & 0.757 & & \\
\hline & EU-2 & 0.912 & 4.91 & 0.54 & 4.32 & 0.832 & & \\
\hline \multirow{4}{*}{$\begin{array}{l}\text { Attitude } \\
\text { toward } \\
\text { discontinuo } \\
\text { us using } \\
\text { social } \\
\text { media }\end{array}$} & AT-2 & 0.876 & 4.90 & 0.45 & 4.18 & 0.767 & \multirow{4}{*}{0.912} & \multirow{4}{*}{0.722} \\
\hline & AT-3 & 0.855 & 5.03 & 0.44 & 4.10 & 0.731 & & \\
\hline & AT-4 & 0.807 & 5.13 & 0.38 & 4.02 & 0.651 & & \\
\hline & AT-1 & 0.858 & 5.23 & 0.38 & 4.14 & 0.736 & & \\
\hline
\end{tabular}


Table 1. Basic fit and internal structural fit (con.)

\begin{tabular}{lcccccccc}
\hline Construct & Q. ID & $\begin{array}{c}\text { Standardized } \\
\text { Factor Load }\end{array}$ & $\begin{array}{c}\text { Avg. } \\
\text { Score }\end{array}$ & $\begin{array}{c}\text { Std. } \\
\text { Dev. }\end{array}$ & Means & $\begin{array}{c}\text { Individual } \\
\text { Item } \\
\text { Reliability }\end{array}$ & $\begin{array}{c}\text { Composite } \\
\text { Reliability }\end{array}$ & $\begin{array}{c}\text { Average } \\
\text { Variance } \\
\text { Extracted }\end{array}$ \\
\hline $\begin{array}{l}\text { Intention of } \\
\text { Discontinuo } \\
\text { us using }\end{array}$ & US-1 & 0.711 & 5.09 & 0.42 & 3.98 & 0.506 & & \\
$\begin{array}{l}\text { social } \\
\text { media }\end{array}$ & US-2 & 0.734 & 5.02 & 0.45 & 4.11 & 0.539 & & \\
\hline & FE-4 & 0.789 & 4.18 & 0.33 & 4.13 & 0.623 & & \\
& FE-3 & 0.946 & 4.68 & 0.39 & 4.34 & 0.895 & & \\
$\begin{array}{l}\text { Flow } \\
\text { experience }\end{array}$ & FE-2 & 0.854 & 4.89 & 0.42 & 4.22 & 0.729 & 0.897 & 0.688 \\
& FE-1 & 0.710 & 3.92 & 0.45 & 4.12 & 0.504 & & \\
\hline
\end{tabular}

Table 2. Discriminant validity

\begin{tabular}{cccccc}
\hline & $\begin{array}{c}\text { Perceived } \\
\text { Usefulness }\end{array}$ & $\begin{array}{c}\text { Perceived } \\
\text { Ease of Use }\end{array}$ & $\begin{array}{c}\text { Attitude toward } \\
\text { Discontinuous } \\
\text { Using Social } \\
\text { Media }\end{array}$ & $\begin{array}{c}\text { Intention of } \\
\text { Discontinuous } \\
\text { Using Social } \\
\text { Media }\end{array}$ & $\begin{array}{c}\text { Flow } \\
\text { Experience }\end{array}$ \\
\hline $\begin{array}{c}\text { Perceived } \\
\text { Usefulness }\end{array}$ & 0.723 & & & \\
\hline $\begin{array}{c}\text { Perceived } \\
\text { Ease of Use }\end{array}$ & 0.706 & 0.784 & & \\
\hline $\begin{array}{c}\text { Attitude toward } \\
\text { Discontinuous } \\
\text { Using Social Media }\end{array}$ & 0.667 & 0.713 & 0.722 & 0.522 & \\
\hline $\begin{array}{c}\text { Intention of } \\
\text { Discontinuous } \\
\text { Using Social Media }\end{array}$ & 0.531 & 0.512 & 0.515 & 0.518 \\
\hline $\begin{array}{c}\text { Flow } \\
\text { Experience }\end{array}$ & 0.323 & 0.457 & 0.458 & 0.688 \\
\hline
\end{tabular}

Figure 3 shows the results of the structural equation modeling of the proposed model. Perceived ease of use positively influences attitude toward discontinuous using social media (the effect is 0.480 , and $\mathrm{H} 1$ is supported). Moreover, perceived usefulness positively influences attitude toward discontinuous using social media (the effect is 0.315 , and $\mathrm{H} 2$ is supported). Additionally, attitude toward discontinuous use of social media positively influences intention to use social media (the effect is 0.315 , and $\mathrm{H} 3$ is supported). Perceived ease of use positively influences perceived usefulness (the effect is 0.840 , and $\mathrm{H} 4$ is supported). Furthermore, flow experience 
positively affects perceived ease of use (H5 is supported), attitude toward discontinuous using social media ( $\mathrm{H} 7$ is supported), and intention to use social media (H8 is supported). The model thus possesses good overall fit ${ }^{57}$ (Table 3).

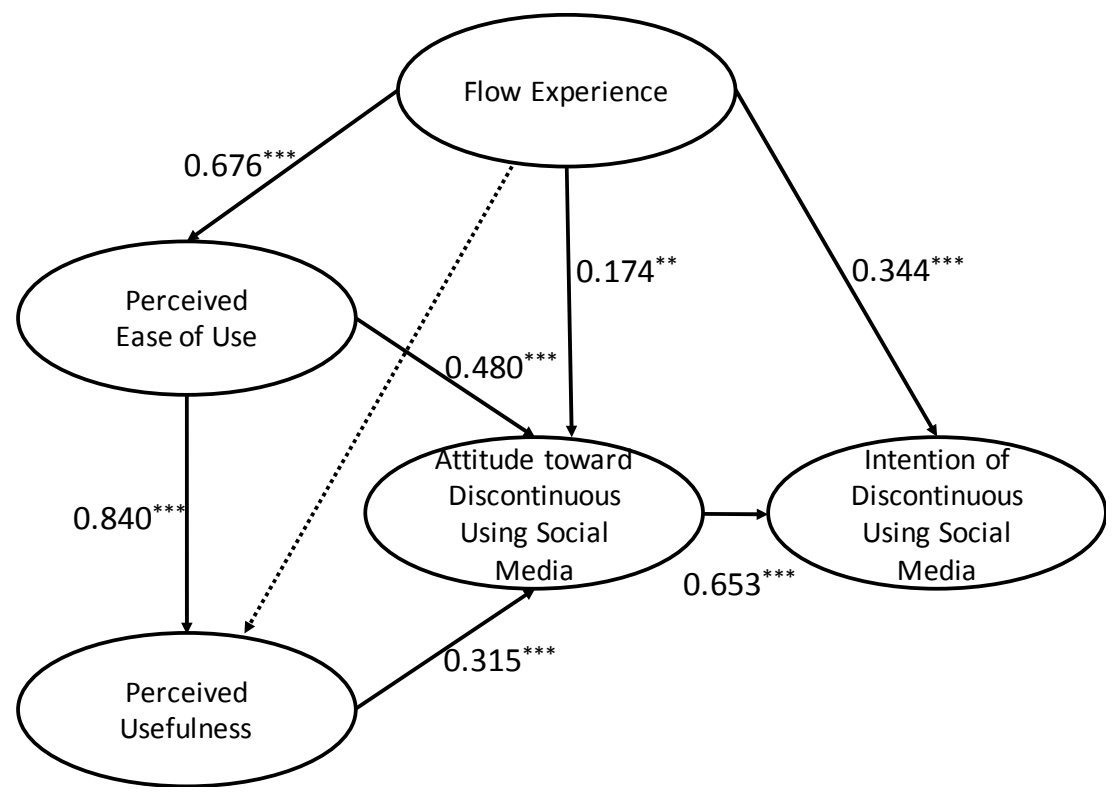

Figure 3. Causal relationships

Table 3. Model fit summary

\begin{tabular}{cccccc}
\hline Statistics & Criteria & Results & Statistics & Criteria & Results \\
\hline & Absolute Fit Indices & \multicolumn{3}{c}{ Parsimony } & Goodness-of-Fit Indices \\
\hline SRMR & $<.05$ & $0.041^{* *}$ & PGFI & $>.50$ & $0.605^{* *}$ \\
RMSEA & $<.08$ & $0.078^{* *}$ & PNFI & $>.50$ & $0.787^{* *}$ \\
GFI & $>.90$ & $0.914^{* *}$ & PCFI & $>.50$ & $0.808^{* *}$ \\
AGFI & $>.90$ & $0.903^{* *}$ & DF of $X^{2}$ & $<3.00$ & $2.505^{* *}$ \\
\hline NFI & $>.90$ & $0.907^{* *}$ & TLI (NNFI) & $>.90$ \\
RFI & $>.90$ & $0.912^{* *}$ & CFI & $>.90$ & $0.901^{* *}$ \\
IFI & $>.90$ & $0.910^{* *}$ & & & $0.910^{* *}$ \\
\hline
\end{tabular}

Note: ${ }^{* *}$ Represents the index is significant. 
Analytical results demonstrate that perceived ease of use significantly influences perceived usefulness (0.840). Perceived ease of use (0.745) and perceived usefulness (0.315) directly influence user habitually preferred social-networking applications and indirectly influence intention to use social media, meaning that if an application permits people to easily communicate or share useful information with their friends, then those people will find the application useful and select it as their preferred socialnetworking application. Regarding the comparison between different social networking applications (i.e. the currently adopted social media and previously favored social media), currently adopted social media enables people to communicate with friends more efficiently than previously adopted social media ${ }^{58}$. The analytical results indicate that flow experience directly influences perceived ease of use (0.676), but does not influence perceived usefulness (insignificant on statistic result). This indicates that people change their social-networking application from their previous favorite social media to the currently adopted one, because they enjoy better flow experience, and because this further influences their perception of the ease of use of social media. The better flow experience enjoyed while using social media results in superior perceived ease of use (0.676) and further influences perceived usefulness (0.568). Such a flow experience also improves attitude toward (0.677) and intention to use a social-networking application $(0.747)^{3}$. In other words, people easily enter a flow state when using social media, thus generating positive usage intention and further actual use ${ }^{2,59}$ (Table 4). A company that seeks to achieve successful social media must consider whether customers should devote more time to its use or are more enthusiastic about this use. 
Table 4. The results of causality relationship

\begin{tabular}{|c|c|c|c|}
\hline path & direct & indirect & total \\
\hline $\begin{array}{c}\text { Flow Experience } \rightarrow \\
\text { Perceived Ease of Use }\end{array}$ & $\begin{array}{c}0.676^{* * * *} \\
(+)\end{array}$ & --- & 0.676 \\
\hline $\begin{array}{l}\text { Flow Experience } \rightarrow \\
\text { Perceived Usefulness }\end{array}$ & ---- & $\begin{array}{c}0.568^{* * *}(+) \\
\text { (through Perceived Ease of Use) }\end{array}$ & 0.568 \\
\hline $\begin{array}{c}\text { Flow Experience } \rightarrow \\
\text { Attitude toward discontinuous } \\
\text { using social media }\end{array}$ & $\begin{array}{c}0.174^{* *} \\
(+)\end{array}$ & $\begin{array}{c}0.324^{* * *}(+) \\
\text { (through Perceived Ease of Use) } \\
0.179^{*}(+) \\
\text { (through Perceived Ease of Use and } \\
\text { Perceived Usefulness) }\end{array}$ & 0.677 \\
\hline $\begin{array}{c}\text { Flow Experience } \rightarrow \\
\text { Intention of Discontinuous } \\
\text { Using Social Media }\end{array}$ & $\begin{array}{c}0.344^{* * * *} \\
(+)\end{array}$ & $\begin{array}{c}\qquad 0.074^{*}(+) \\
\text { (through Change the Attitude } \\
\text { toward Social Media) } \\
0.212^{* * *}(+) \\
\text { (through Perceived Ease of Use and } \\
\text { Change the Attitude toward Social } \\
\text { Media) } \\
0.117^{* *}(+) \\
\text { (through Perceived Ease of Use, } \\
\text { Perceived Usefulness, and Change } \\
\text { the Attitude toward Social Media) }\end{array}$ & 0.747 \\
\hline $\begin{array}{c}\text { Perceived Ease of Use } \rightarrow \\
\text { Perceived Usefulness }\end{array}$ & $\begin{array}{c}0.840^{* * *} \\
(+)\end{array}$ & ---- & 0.840 \\
\hline $\begin{array}{c}\text { Perceived Ease of Use } \rightarrow \\
\text { Attitude toward discontinuous } \\
\text { using social media } \\
\end{array}$ & $\begin{array}{c}0.480^{* * *} \\
(+)\end{array}$ & $\begin{array}{c}0.265^{* * *}(+) \\
\text { (through Perceived Usefulness) }\end{array}$ & 0.745 \\
\hline $\begin{array}{c}\text { Perceived Usefulness } \rightarrow \\
\text { Attitude toward discontinuous } \\
\text { using social media }\end{array}$ & $\begin{array}{l}0.315^{* * *} \\
(+)\end{array}$ & ---- & 0.315 \\
\hline $\begin{array}{c}\text { Attitude toward discontinuous } \\
\text { using social media } \rightarrow \\
\text { Intention of Discontinuous } \\
\text { Using Social Media } \\
\end{array}$ & $\begin{array}{c}0.653^{* * *} \\
(+)\end{array}$ & ---- & 0.653 \\
\hline $\begin{array}{c}\text { Perceived Usefulness } \rightarrow \\
\text { Intention of Discontinuous } \\
\text { Using Social Media } \\
\end{array}$ & ---- & $\begin{array}{c}0.206^{* * *}(+) \\
\text { (through Attitude toward } \\
\text { discontinuous using social media) }\end{array}$ & 0.206 \\
\hline $\begin{array}{c}\text { Perceived Ease of Use } \rightarrow \\
\text { Intention of Discontinuous } \\
\text { Using Social Media }\end{array}$ & ---- & $\begin{array}{c}0.313^{* * *}(+) \\
\text { (through Attitude toward } \\
\text { discontinuous using social media) } \\
0.173^{* * *}(+) \\
\text { (through Perceived Usefulness and } \\
\text { Attitude toward discontinuous } \\
\text { using social media) }\end{array}$ & 0.486 \\
\hline
\end{tabular}

Note: ${ }^{*}$ Represents the value is significant. 


\section{Discussion}

The analytical results show that flow experience affects the discontinuous adoption of a chat software application. It can enhance the understanding of discontinuous behavior. Combining flow experience with technology acceptance model is not a new concept, but the application to the discontinuous use is worthy of investigation in future studies.

For managerial implication, the analytical results indicate that a company wanting to make users change their preferred social media platform must enhance its flow experiences. Enhancing flow experiences directly enhances a user's attitude, intention to use a social media platform, and perceived ease of use and enhances perceived usefulness indirectly through perceived ease of use. Therefore, enhancing a user's flow experiences is an important issue to address.

However, the solution to Facebook's decrease in revenue in 2016 offered a different approach. Facebook attempted to increase its user adoption by encouraging users to share their personal information, because such sharing had been gradually falling ${ }^{60}$. Of course, users willing to share personal information tend to spend more time on social media ${ }^{61,62}$. By actively creating events, Facebook is not only trying to make customers loyal, but also to increase customer purchases via Facebook advertisements. Facebook tried to push people to share data, but it must also pay attention to user flow experiences according to the analytical results collected.

Facebook can attempt to enhance user flow experiences in order to retain users in this fierce market. It can create events or games to attract users' attention. Of course, interactive events or games should link with each user's social network, namely friends and family, thus reflecting the original purpose of social media. Whether or not historical events on Facebook increase user flow experiences is unclear. Facebook should try to focus on identifying factors that improve flow status, such as elements that can continuously attract customers' full attention on their reactions to Facebook events. Users can extend their flow statuses by combining the finding factors with the event. Newcomers can focus on how to enhance user flow experiences or focus and further change user intentions toward adopting different social media. For instance, users have increasingly shared their personal information on Instagram instead of Facebook, because they are willing to share photos via specified social networks that allow them to control who can view their photos. Accordingly, users of Instagram must pay more attention to their shared photos and generate feedback from their followers ${ }^{48,63}$. 


\section{Conclusion}

This study clarified the causal relationships among the above factors. The results of this investigation illustrate that, if an application can help people easily communicate or share useful information with their friends, then they will find that application easy to use and useful and eventually adopt it habitually. This study indicates that people will use a social media application if it can help them effectively and efficiently communication with friends. This study found that flow experience indirectly and positively influences perceived usefulness and directly and positively affects perceived ease of use. In other words, people adopt new social-network applications based on their positive flow experiences while using social media. Furthermore, if people easily enter a flow state when using their favorite social media, they will generate positive feelings about its use. The factors analyzed in this study include technology acceptance and flow status, but several other factors also affect user adoption of a service. For example, Theory of Planned Behavior is worth study for the discontinuous adoption of a software service, but it is not discussed in this work. Additionally, although the factors that can improve customer flow status warrant discussion, they are not included in this investigation.

\section{REFERENCES}

[1] Micorsoft, Inc., Windows Live Messenger, 2016, Retrieved on December 31, 2016, from http://en.wikipedia.org/wiki/Windows_Live_ Messenger.

[2] M. A. Moreno, R. Kota, S. Schoohs, and J. M. Whitehill, The Facebook Influence Model: A concept mapping approach. Cyberpsychology, Behaviour, and Social Networking, 16(7), p504-511, 2013. http://dx.doi.org/10.1089/cyber.2013.0025.

[3] M. Mauri, P. Cipresso, A. Balgera, M. Villamira, and G. Riva, Why is Facebook so successful? Psychophysiological measures describe a core flow state while using Facebook. Cyberpsychology, Behaviour, and Social Networking, 14(12), p723-731, 2011. http://dx.doi.org/10.1089/cyber.2010.0377.

[4] A. Maksl, and R. Young, Affording to exchange: Social capital and online information sharing. Cyberpsychology, Behaviour, and Social Networking, 16(8), p588-592, 2013.

[5] comScore. 2013 China-Taiwan-Hong Kong Digital Future in Focus. Retrieved May 20, 2014, from http://www.comscore.com/Insights/Presentations_and_Whitepapers.

[6] P. Collin, Building and connecting to online communities for action: Young people, ICT and everyday politics. E-Politics and 
Organizational Implications of the Internet: Power, Influence, and Social Change: Power, Influence, and Social Change, 1(3), p114, 2012. http://dx.doi.org/10.4018/jep.2010070101.

[7] I. Im, Y. Kim, and H. J. Han, The effects of perceived risk and technology type on users' acceptance of technologies. Information \& Management, 45(1), p1-9, 2008. http://dx.doi.org/10.1016/j.im.2007.03.005.

[8] W. A. Warr, Social software: Fun and games, or business tools? Journal of Information Science, 34(8), p591-604, 2008. http://dx.doi.org/10.1177/0165551508092259.

[9] X. Zhang, P. O. de Pablos, X. Wang, W. Wang, Y. Sun, and J. She, Understanding the users' continuous adoption of 3D social virtual world in China: A comparative case study. Computers in Human Behavior, 35, p578-585, 2014. http://dx.doi.org/10.1016/j.chb.2014.02.034.

[10] T. Kelleher, and K. Sweetser, Social media adoption among university communicators. Journal of Public Relations Research, 24(2),p105-122, 2012. http://dx.doi.org/10.1080/1062726X.2012.626130.

[11] B. W. Wirtz, and V. Göttel. Technology acceptance in social media: Review, synthesis and directions for future empirical research. Journal of Electronic Commerce Research, 17(2), p97-115, 2016.

[12] C. C. Liang, and Y. W. Huang. Employee's intention on social media evolvement-A case study of MSN messenger and Facebook. Business Review, 18(2), p79-106.

[13] C. C. Frangos, C. C. Frangos, and I. Sotiropoulos, Problematic internet use among Greek university students: An ordinal logistic regression with risk factors of negative psychological beliefs, pornographic sites, and online games. Cyberpsychology, Behaviour, and Social Networking, 14(1-2), p51-58, 2011. http://dx.doi.org/10.1089/cyber.2009.0306.

[14] K. Heinonen, Consumer activity in social media: Managerial approaches to consumers' social media behaviour. Journal of Consumer Behaviour, 10(6), p356-364, 2011. https://doi.org/10.1002/cb.376.

[15] V. Venkatesh, and F. D. Davis, A theoretical extension of the technology acceptance model: Four longitudinal field studies. Management Science, 46(2), p186-204, 2000. http://dx.doi.org/10.1287/mnsc.46.2.186.11926.

[16] D. Gefen, D., and Straub, D. W., The relative importance of perceived ease of use in IS adoption: A study of e-commerce adoption. Journal of AIS, 1, p1-28, 2000. http://dx.doi.org/10.17705/1jais.00008.

[17] E. Karahanna, and D. W. Straub, The psychological origins of perceived usefulness and ease-of-use. Information \& Management, 
35(4), p237-250, 1999. http://dx.doi.org/10.1016/S03787206(98)00096-2.

[18] J. Yu, I. Ha, M. Choi, and J. Rho, Extending the TAM for a tcommerce. Information \& Management, 42(7), p965-976, 2005. http://dx.doi.org/10.1016/j.im.2004.11.001.

[19] S.M. Lee, and L. Chen, The impact of flow on online consumer behaviour. Journal of Computer Information Systems, 50(4), p1-10, 2010.

[20] C. M. Segijn, H. A. Voorveld, and E. G. Smit, The underlying mechanisms of multiscreening effects. Journal of Advertising, p1-12, 2016. http://dx.doi.org/10.1080/00913367.2016.1172386.

[21] A. Carù, and B. Cova, How to facilitate immersion in a consumption experience: Appropriation operations and service elements. Journal of Consumer Behaviour, 5(1), p4-14, 2006.

[22] J. H. Heinrichs, J. S. Lim, and K. S. Lim, Influence of social networking site and user access method on social media evaluation. Journal of Consumer Behaviour, 10(6), p347-355, 2011. https://doi.org/10.1002/cb.377.

[23] C. L. Hsu, and H. P. Lu, Why do people play on-line games? An extended TAM with social influences and flow experience. Information \& Management, 41(7), p853-868, 2004. http://dx.doi.org/10.1016/j.im.2003.08.014.

[24] M. Koufaris, Applying the technology acceptance model and flow theory to online consumer behavior. Information Systems Research, 13(2), p205-223, 2002. http://dx.doi.org/10.1287/isre.13.2.205.83.

[25] A. Chronis, and R. D. Hampton, Consuming the authentic Gettysburg: How a tourist landscape becomes an authentic experience. Journal of Consumer Behaviour, 7(2), p111-126, 2008. https://doi.org/10.1002/cb.241.

[26] G. Riva, R. M. Banos, C. Botella, B. K. Wiederhod, and A. Gaggioli, Positive technology: Using interactive technologies to promote positive functioning. Behaviour, and Social Networking, 15(2), p69-77, 2012. http://dx.doi.org/10.1089/cyber.2011.0139.

[27] J. W. Moon, and Y. G. Kim, Extending the TAM for a World-WideWeb context. Information \& Management, 38(4), p217-230, 2001. http://dx.doi.org/10.1016/S0378-7206(00)00061-6.

[28] W. L. Shiau, L. C. Huang, and C. H. Shih, Understanding continuance intention of blog users: A perspective of flow and expectation confirmation theory. Journal of Convergence Information Technology, 6(4), p306-317, 2011.

[29] F. Xiong, Y. Liu, and J. Cheng, Modeling and predicting opinion formation with trust propagation in online social networks. Communications in Nonlinear Science and Numerical 
Simulation, 44,p513-524,2017.

http://dx.doi.org/10.1016/j.cnsns.2016.09.015.

[30] D. Lazer, A. Pentland, L. Adamic, S. Aral, A.L. Barabassi, D. Brewer, N. Christakis, N. Contractor, J. Fowler, M. Gutmann, T. Jebara, G. King, M. Macy, D. Roy, and V. Alstyne, Life in the network:The coming age of computational social science. Science, 323(5915), p721723, 2009. https://dx.doi.org/10.1126\%2Fscience.1167742.

[31] P. Ifinedo, Applying uses and gratifications theory and social influence processes to understand students' pervasive adoption of social networking sites: Perspectives from the Americas. International Journal of Information Management,36(2), p192-206, 2016. https://doi.org/10.1016/j.ijinfomgt.2015.11.007.

[32] K. Lee, A. Yan, and K. Joshi, Understanding the dynamics of users' belief in software application adoption. International Journal of Information Management, 31(2), p160-170, 2011. http://dx.doi.org/10.1016/j.ijinfomgt.2010.07.009.

[33] P. Louridas, Up in the air: Moving your applications to the cloud. Software, IEEE, 27(4), p6-11, 2010. http://dx.doi.org/10.1109/MS.2010.109.

[34] O. I. Franko, and T. F. Tirrell, Smartphone App use among medical providers in ACGME training programs. Journal of medical systems, 36(5), p3135-3139, 2011. http://dx.doi.org/10.1007/s10916-011-97987.

[35] M. Maguire, Using Human factors standards to support user experience and agile design. Lecture Notes in Computer Science, 8009, p185-194, 2013. http://dx.doi.org/10.1007/978-3-642-39188-0_20.

[36] E. G. Nilsson, Design patterns for user interface for mobile applications. Advances in Engineering Software, 40(12), p1318-1328, 2009. http://dx.doi.org/10.1016/j.advengsoft.2009.01.017.

[37] J. T. Marchewka, C. Liu, and K. Kostiwa, An Application of the UTAUT model for understanding student perceptions using course management software. Communication of IIMA, 7(2), p93-104, 2007.

[38] C. C. Wang, S. K. Lo, and W. Fang, Extending the technology acceptance model to mobile telecommunication innovation: The existence of network externalities. Journal of Consumer Behaviour, 7(2), p101-110, 2008. https://doi.org/10.1002/cb.240.

[39] B. M. Evans, S. Kairam, and P. Pirolli, Do your friends make you smarter? An analysis of social strategies in online information seeking. Information Processing \& Management, 46(6), p679-692, 2010. http://dx.doi.org/10.1016/j.ipm.2009.12.001.

[40] R. A. Sánchez, V. Cortijo, and U. Javed, Students' perceptions of Facebook for academic purposes. Computers \& Education, 70, p138149, 2014. 
[41] D. H. Shin, The effects of trust, security and privacy in social networking: A security-based approach to understand the pattern of adoption. Interacting with Computers, 22(5), p428-438, 2010. http://dx.doi.org/10.1016/j.intcom.2010.05.001.

[42] Y. Lu, T. Zhou, and B. Wang, Exploring Chinese users' acceptance of instant messaging using the theory of planned behaviour, the technology acceptance model, and the flow theory. Computers in Human Behaviour, 25(1), p29-39, 2009. https://doi.org/10.1016/j.chb.2008.06.002.

[43] B. A. Martin, C. K. C. Lee, C. Weeks, and M. Kaya, How to stop binge drinking and speeding motorists: Effects of relational-interdependent self-construal and self-referencing on attitudes toward social marketing. Journal of Consumer Behaviour, 12(1), p81-90, 2013. https://doi.org/10.1002/cb.1417.

[44] M. Castells, The rise of the network society: The information age: Economy, society, and culture (2nd Ed). Wiley-Blackwell, 2011.

[45] A. M. Kaplan, and M. Haenlein, Users of the world, unite! The challenges and opportunities of social media. Business Horizons, 53(1), p59-68, 2010. http://dx.doi.org/10.1016/j.bushor.2009.09.003.

[46] W. Kim, O. R. Jeong, and S.W. Lee, On social Web sites. Information Systems, 35(2), p215-236, 2010. http://dx.doi.org/10.1016/j.is.2009.08.003.

[47] N. B. Ellison, C. Steinfield, and C. Lampe, Connection strategies: Social capital implications of Facebook-enabled communication practices. New Media \& Society, 13(6), p873-892, 2011. http://dx.doi.org/10.1177/1461444810385389.

[48] M. Csikszentmihalyi, Toward a psychology of optimal experience. In Flow and the Foundations of Positive Psychology, p209-226. Springer Netherlands, 2014. http://dx.doi.org/10.1007/978-94-017-9088-8_14.

[49] M. Csikszentmihalyi, Flow: The Psychology of Optimal Performance. New York: Cambridge University Press, 1990.

[50] I. V. Kozlenkova, R. W. Palmatier, E. Fang, B. Xiao and M. Huang, Online relationship formation. Journal of Marketing, 81(3), p21-40, 2017. http://dx.doi.org/10.1509/jm.15.0430.

[51] Y. Jung, B. Perez-Mira, and S. Wiley-Patton, Consumer adoption of mobile TV: Examining psychological flow and media content. Computers in Human Behaviour, 25(1), p123-129, 2009. http://dx.doi.org/10.1016/j.chb.2008.07.011.

[52] H. C. Chiu, Quantitative Research and Statistical Analysis in Social \& Behavioural Sciences. Wu-Nan Book Inc, Taipei, 2003.

[53] J. C. Nunnally, Psychometric Theory. McGraw-Hill, 1978. 
[54] A. L. Comrey, and H. B. Lee, Interpretation and application of factor analytic results. In A. L. Comrey, and H. B. Lee (Ed.), A First Course In Factor Analysis, 2, 1992.

[55] J. S. Chen, H. J. R. Yen, E. Y. Li, and R. K. H. Ching, Measuring CRM effectiveness: Construct development, validation and application of a process-oriented model. Total Quality Management \& Business Excellence, 20(3), p283-299, 2009. http://dx.doi.org/10.1080/14783360902719451.

[56] C. Fornell, and D. F. Larcker, Evaluating structural equation models with unobservable variables and measurement error. Journal of Marketing Research, 18(1), p39-50, 1981.

[57] D. L. Jackson, Revisiting sample size and number of parameter estimates: Some support for the N:q hypothesis. Structure Equation Modeling, 10, p128-141, 2003. http://dx.doi.org/10.1207/S15328007SEM1001_6.

[58] C. Piotrowski, Emerging research on social media use in education: A study of dissertations. Research in Higher Education Journal, 27, 2015.

[59] K.Y. Lin, and H. P. Lu, Why people use social networking sites: An empirical study integrating network externalities and motivation theory. Computers in Human Behaviour, 27(3), p1152-1161, 2011. http://dx.doi.org/10.1016/j.chb.2010.12.009.

[60] A. Heath, Facebook sees personal sharing decline. December 31, 2016, from http://www.techinsider.io/facebook-seespersonal-sharing-decline-2016-4.

[61] T. S. Chang, and W. H. Hsiao, Time spent on social networking sites: Understanding user behavior and social capital. Systems Research and Behavioral Science, 31(1), p102-114, 2014. http://dx.doi.org/10.1002/sres.2169.

[62] G. S. Mesch, Parental mediation, online activities, and cyberbullying. CyberPsychology \& Behavior, 12(4), p387-393, 2009. http://dx.doi.org/10.1089/cpb.2009.0068.

[63] J. Jang, J. Kim, H. Shin, H. Aum, and J. Kim, Effects of temporal format of everyday video on narrative engagement and social interactivity. Interacting with Computers, iwv043, 2016. https://doi.org/10.1093/iwc/iwv043. 


\section{Appendix 1. Questionnaire Items}

\begin{tabular}{|c|c|c|}
\hline Q.No & Item & Source \\
\hline \multicolumn{3}{|c|}{ Perceived Ease of Use } \\
\hline EU-1 & $\begin{array}{l}\text { The social media I currently use is easier to use than my } \\
\text { previous favorite. }\end{array}$ & \multirow{7}{*}{$\begin{array}{l}\text { Lee } \text { et } a l .{ }^{32} ; \\
\text { Louridas }^{33} ; \\
\text { Marchewka } \text { et } \text { al. }^{37}\end{array}$} \\
\hline EU-2 & $\begin{array}{l}\text { The functions of the social media I currently use are } \\
\text { easier to understand than those of my previous favorite. }\end{array}$ & \\
\hline EU-3 & $\begin{array}{l}\text { The interface of the social media I currently use is more } \\
\text { user-friendly than that of my previous favorite. }\end{array}$ & \\
\hline EU-4 & $\begin{array}{l}\text { I can publish my comments using the social media I } \\
\text { currently use easier than on my previous favorite. }\end{array}$ & \\
\hline EU-5 & $\begin{array}{l}\text { I can learn the functions of the social media I currently } \\
\text { use sooner than I can learn those of my previous } \\
\text { favorite. }\end{array}$ & \\
\hline EU-6 & $\begin{array}{l}\text { I experience the fluent interactions of the social media I } \\
\text { currently use more than I can experience those of the } \\
\text { one I previously used. }\end{array}$ & \\
\hline EU-7 & $\begin{array}{l}\text { I can be competent for using the social media I currently } \\
\text { use sooner than the one I previously used. }\end{array}$ & \\
\hline
\end{tabular}

\section{Perceived Usefulness}

The social media I currently use can provide more

PU-1 useful information to me than can my previous favorite.

The social media I currently use can bring me more

PU-2 interesting information than can the one I previously used.

Evans et al. ${ }^{39} ;$ Lee et

The social media I currently use enables me to find al. ${ }^{32}$; Marchewka et required information sooner than does my previous $a l .{ }^{37} ; \mathrm{Shin}^{41}$

PU-3 required
favorite.

The social media I currently use enables me to

PU-4 communicate with my friends more information than does the one I previously used. 


\section{Appendix 1. Questionnaire Items (Conti.)}

Attitude toward discontinuous using social media

AT-1 I would rather to recommend the social media I currently use over the one I previously used.

AT-2 I would rather to use the social media I currently use than the one I previously used.

AT-3 The social media I currently use can relax me more than my previous favorite.

Castells ${ }^{44}$; Ellison, et $a .^{47}$; Kaplan and Haenlein $^{45}$; Kim et $a l^{46}$

AT-4 I experience more fun from the social media I currently use than the one I previously used.

\section{Intention of Discontinuous Using Social Media}

US-1 I have abandoned my previous favorite social media.

US-2 I love the social media I currently use, but I don't want to use the previous one continuously.

I am happy to see my friends use my current favored

US-3 social media application to communicate with me, but I no longer want to use the previous social media.

Castells ${ }^{44}$; Ellison, et $a .^{47}$; Kaplan and Haenlein $^{45}$; Kim et $a l^{46}$

US-4

I use my current favored social media application to announce my daily life instead of the previous one.

\section{Flow Experience}

The social media I currently use holds my

FE-1 concentration more than does the one I previously used.

FE-2 I more easily spend more time on the social media I currently use than on the one I previously used.

I am more enthusiastic about the social media I

Csikszentmihalyi ${ }^{49}$; Mauri et al. $^{3}$

FE-3 currently use than I am about the one I previously used.

FE-4 My current favored social media is more exciting than my previous favorite. 
